\title{
Antioxidant defense in rat tissues after supplementation with organic form of manganese
}

\author{
Aleksandra Jankovic ${ }^{1}$ \\ Milica Vucetic ${ }^{1}$ \\ Ana Stancic ${ }^{1}$, \\ Vesna Otasevic ${ }^{1}$ \\ Bato Korac ${ }^{1,2}$ \\ Biljana Buzadzic ${ }^{1}$
}

${ }^{1}$ University of Belgrade, Institute for Biological Research "Sinisa Stankovic", Department of Physiology, 11060 Belgrade, Serbia. 2 University of Belgrade, Faculty of Biology, 11000 Belgrade, Serbia

Rad primljen: 20.03.2014

Corresponding author: Biljana Buzadzic, PhD University of Belgrade Institute for Biological Research "Sinisa Stankovic" Department of Physiology Bulevar despota Stefana 142 11060 Belgrade, Serbia Tel: (381-11)-2078-307 Fax: (381-11)-2761-433 E-mail: buzadzic@ibiss.bg.ac.rs

\begin{abstract}
This study investigated the effect of $\mathrm{Mn}$ chelate supplementation on the activity of antioxidant enzymes: copper zincand manganese- superoxide dismutase (CUZnSOD and MnSOD), catalase (CAT), glutathione peroxidase (GSH-PX), glutathione reductase (GR), glutathione S-transferase (GST) and the amount of glutathione (GSH) in the blood, liver, brain, heart and small intestine of the rat. Increased Mn intake of 34\% above daily intake (0.851 \pm $0.045 \mathrm{mg} \mathrm{Mn} \mathrm{/} \mathrm{kg}$ b.wt.) induced changes in the antioxidant defense in the tissues of the rat.

Decreased activity of peroxides-converting enzymes CAT and GSH$P x$ was found in all examined tissues (except GSH-Px activity in the liver). The amount of GSH was increased in plasma and liver, while it was decreased in heart and brain of supplemented animals. Treatment with Mn increases MnSOD activity in the liver, and CuZnSOD activity in the heart.

The observed changes in antioxidant defense are closely connected with the newly established redox profile in the examined tissues after Mn supplementation.
\end{abstract}

Key words: Manganese; metal chelate; antioxidant enzymes; glutathioner.

\section{INTRODUCTION}

Manganese is one of several first-row transition elements that assist in various metabolic and structural roles in biological system. It is used to give structural support to proteins and it is a cofactor in chemical transformation that include hydrolytic and redox reactions. Some of the enzymes that contain manganese are arginase, pyruvate carboxylase, glutamine synthetase and the enzymes that catalyze redox-based chemical transformations: manganese superoxide dismutase (MnSOD), manganese peroxidase, and manganese dioxygenase [1].

No cases of human manganese deficiency have been recorded [2]. In animals, manganese deficiency can cause impaired growth, skeletal abnormalities, and altered metabolism of carbohydrates and lipids [3]. Food items are the most important sources of essential trace elements. Mineral requirements are highly dependent on the physiological and health status of the animals and humans. In many situations additional mineral supplementation is recommended. The effort has been made to provide minerals in correct quantities and in the most available forms to the animals and humans. As a consequence there has been increasing interest in the role of organic sources of trace elements, frequently described as chelates and proteinates $[4,5]$. Also, it has been proposed that mineral chelates may utilize peptide or amino acid uptake pathways, rather than normal mineral uptake in the small intestine [6].

ROS are produced as part of many normal biological processes, and they may be both essential and detrimental to life [7]. In biological systems a diversity of antioxidant defense systems operates to control excessive level of the ROS. Enzymatic detoxification involves trace elements, particularly $\mathrm{Cu}, \mathrm{Mn}, \mathrm{Se}, \mathrm{Zn}$, and $\mathrm{Fe}$, which function at the active sites of metal ion-dependent enzymes, such as SOD, catalase (CAT) and glutathione peroxidase (GSH-Px). With respect to human and animal nutrition, the potential benefit to health of antioxidants supply, either through dietary means or as nutritional supplements, came in the focus of the research in the last years.

Many factors affect mineral requirements, including age, amount and chemical forms of elements and their interrelationships with other nutrients. Because many factors are involved in bioavailability of dietary inorganic trace elements, the alternative approaches and sources were examined. The ability of metals to both 'heal' and 'harm', has led to the development of a wide range of mechanisms that regulate metal uptake and distribution in tissues. It is known that gastrointestinal absorption for organometallic species is more efficient than inorganic forms [8].

In order to increase the content and bioavailability of trace minerals some authors tried to increase the total level of minerals in plant foods, and at the same time to increase the concentration of compounds which promote their uptake (ascorbic acid), and/or to decrease the concentration of compounds which inhibit their absorption (phytic acid or phenolic compounds) [9]. The inclusion of organic complexes or chelated mineral products into supplements has been suggested on the basis of their higher bioavailability as compared to inorganic mineral salts $[10,11,12$ and 13$]$. For mineral proteinates, it had been shown that, beside higher bioavailability, they are also more bioactive [14].

It is known that $\mathrm{Mn}$ possesses ability to change its oxidative state and to generate reactive oxygen species (ROS). Dose-dependent increase in formation of ROS was found after in vitro exposure to $\mathrm{MnCl}_{2}$ in the rat brain [15]. Contrary 
to this, Mn has important role as a constituent of the antioxidant enzyme MnSOD, which catalyzes the dismutation of superoxide anion radical $\left(\mathrm{O}_{2} \bullet-\right)$. Also, high intracellular manganese has been known to suppress oxidative stress $[16,17]$. As, $\mathrm{Mn}$ may play a role in maintaining a healthy balance between oxidants and antioxidants [18], in the present study, the effects of supplementation with $\mathrm{Mn}$ proteinates on the antioxidant defense components: CuZnSOD, MnSOD, CAT, GSH-Px, glutathione reductase (GR), glutathione S-transferase (GST), and the amount of glutathione (GSH), in the blood, liver, brain, heart and small intestine of the rats, were examined.

\section{Materials and methods}

Male rats (Mill Hill hybrid hooded, age 4 months) were divided into two groups (six animals within each group). Body weght in control group was $370 \pm 12 \mathrm{~g}$ and in $\mathrm{Mn}$-supplemented group $395 \pm 13 \mathrm{~g}$. All animals were housed in individual cages with woodshop bedding at $20-25^{\circ} \mathrm{C}$ and fed the same pelleted rat diet. The control group had food and water ad libitum, and the test group was supplemented with the organic form of manganese (chemically bound to amino acids and small peptides as a chelating agents) - Bioplex Mn liquid (Alltech Inc., USA) through drinking water for 45 days. At the end of experiments the intake of $\mathrm{Mn}$ was calculated. The rats received trough drinking water $0.323 \mathrm{mg}$ Mn/animal/day, which for 34\% above the standard amount in the control diet. Expresed per body weights, animals received $0.851 \pm 0.045 \mathrm{mg} \mathrm{Mn} / \mathrm{kg}$. The experimental protocol was approved by the Ethical Committee for the Treatment of Experimental Animals of the Institute for Biological Research, Belgrade.

The rats were sacrificed by decapitation and fresh heparinized blood was collected. The erythrocytes and plasma were separated by centrifugation. Erythrocytes were washed three times with saline and lysed with cold water. The liver was perfused with a cold physiological saline solution and samples of all organs (liver, heart, brain and small intestine) were dissected within 3 min after death, and thoroughly rinsed with saline to wash out trace of blood. The obtained samples were homogenized (Janke and Kunkel Ka/Werke Ultra/Turrax homogenizer, $0-4^{\circ} \mathrm{C}$ ) in a solution containing $0.25 \mathrm{mM}$ ethylenediaminetetraacetic acid (EDTA) and $0.05 \mathrm{M}$ Tris- $\mathrm{HCl}$ buffer, $\mathrm{pH} 7.4$. The homogenates were sonicated as suggested by Takada et al. [19]. SOD activity was examined by a modified method of Misra and Fridovich [20], and expressed in $\mathrm{U} \mathrm{g}^{-1} \mathrm{Hb}$ for erythrocytes and $\mathrm{U} \mathrm{mg}^{-1}$ protein for the respective tissues. SOD units are defined as the amount of the enzyme inhibiting epinephrine oxidation by $50 \%$ under the appropriate reaction conditions. Total specific SOD activity and CuZnSOD activity after inhibition with $4 \mathrm{mM} \mathrm{KCN}$, were measured, and then MnSOD activity was calculated. CAT was assayed as suggested by supplier (SIGMA Chemicals, St. Luis, MO, USA) and activity expressed as $\mu \mathrm{mol}_{2} \mathrm{O}_{2}$ min $^{-}$ ${ }^{1} \mathrm{~g}^{-1} \mathrm{Hb}$ for erythrocytes, and $\mu \mathrm{mol} \mathrm{H}_{2} \mathrm{O}_{2} \mathrm{~min}^{-1} \mathrm{mg}^{-1}$ protein of the tissue. GSH-Px was determined using t-butilhydroperoxide as a substrate [21] and the activity expressed as nmol of NADPH oxidized $\mathrm{min}^{-1}$ per $\mathrm{mg} \mathrm{Hb}$ for erythrocytes, and per $\mathrm{mg}$ protein for tissue. GR was assayed as suggested by Glatzle et al. [22] and expressed as nmol NADPH min $^{-1} \mathrm{mg}^{-1}$ protein for the tissue. GST was determined by the procedure of Habig et al. [23] and the activity was expressed as nmol GSH $\mathrm{min}^{-1} \mathrm{mg}^{-1}$ protein. The quantity of GSH was examined in the plasma and in the tissues after deproteinization with $10 \%$ sulfosalicylic acid. The GSH was determined by using the method of Griffith [24] and results were expressed as nM $\mathrm{GSH} \mathrm{L}^{-1}$ plasma and nM GSH g ${ }^{-1}$ tissue.

Protein content was estimated by the method of Lowry et al. [25].

Student's t-test was used for data comparison between different groups according to Hoel [26]. The 0.05 level was selected as the point of minimal acceptable statistical significance.

\section{RESULTS}

The effects of $\mathrm{Mn}$ proteinate on the activities of antioxidant enzymes: CuZnSOD, MnSOD, CAT, GSH-Px, GST and GR, and the amount of GSH, were

Table 1. Specific activity of CuZnSOD, MnSOD, GR and GST in the erythrocytes, liver, heart, brain and small intestine of the control and Mn-supplemented group.

\begin{tabular}{|l|l|l|l|l|l|}
\hline & & CuZnSOD & MnSOD & GR & GST \\
\hline ERYTHROCYTES & control & $5314 \pm 207$ & - & - & - \\
\hline (U g-1 Hb) & Mn & $4020 \pm 170 \quad * * *$ & - & - & - \\
\hline LIVER & control & $28.0 \pm 2.3$ & $4.3 \pm 0.1$ & $139 \pm 3.1$ & $3063 \pm 119$ \\
\hline (U mg-1 protein) & Mn & $32.1 \pm 1.8$ & $4.8 \pm 0.2 * *$ & $151 \pm 3.1 * * *$ & $3114 \pm 154$ \\
\hline HEART & control & $14 \pm 1.1$ & $9.9 \pm 0.2$ & $32.9 \pm 0.94$ & $156 \pm 8$ \\
\hline (U mg-1 protein) & Mn & $16.4 \pm 1.4 * *$ & $8.8 \pm 0.8$ & $39.9 \pm 1.9 \quad * *$ & $160 \pm 12$ \\
\hline BRAIN & control & $32.8 \pm 4.1$ & $6.6 \pm 0.03$ & $70.0 \pm 1.3$ & $431 \pm 21$ \\
\hline (U mg-1 protein) & Mn & $29.4 \pm 1.4$ & $6.9 \pm 0.2$ & $75.7 \pm 2.0$ & $457 \pm 11$ \\
\hline SMALL INTESTINE & control & $12.8 \pm 0.9$ & $2.5 \pm 0.07$ & $358 \pm 10$ & $353 \pm 5$ \\
\hline (U mg-1 protein) & Mn & $11.6 \pm 0.7$ & $2.2 \pm 0.13$ & $605 \pm 22 * * *$ \\
\hline
\end{tabular}

For definitions of units see the Materials and Methods section. Results are $M \pm S D, n=6$.

$* * * \mathrm{P}<0.005 ; * * \mathrm{P}<0.025$ 
evaluated in the blood, liver, heart, small intestine and brain of the control and Mn-supplemented rats.

The activities of CuZnSOD, MnSOD, GR and GST in the blood and tissues of control and $M n$ suplemented rats are presented in Table 1. Activity of CuZnSOD in the erythrocytes was significantly decreased in the Mn-supplemented group ( $\mathrm{P}<$ 0.005), while in the heart of the same group of animals, treatment with $\mathrm{Mn}$ increased CuZnSOD activity, compared with the corresponding control $(P<0.025)$. Also, MnSOD activity in the liver was increased in this group $(P<0.025)$. The activity of GR increased after Mn supplementation in the liver $(P<0.005)$ and heart $(P<0.025)$. The GR activity in the small intestine was significantly higher $(\mathrm{P}<$ 0.005 ) in animals supplemented with $\mathrm{Mn}$.

GSH-Px activity in the erythrocytes and tissues of rat were depicted in the Figure 1 . Decrease in the activity was found after Mn-supplementation in

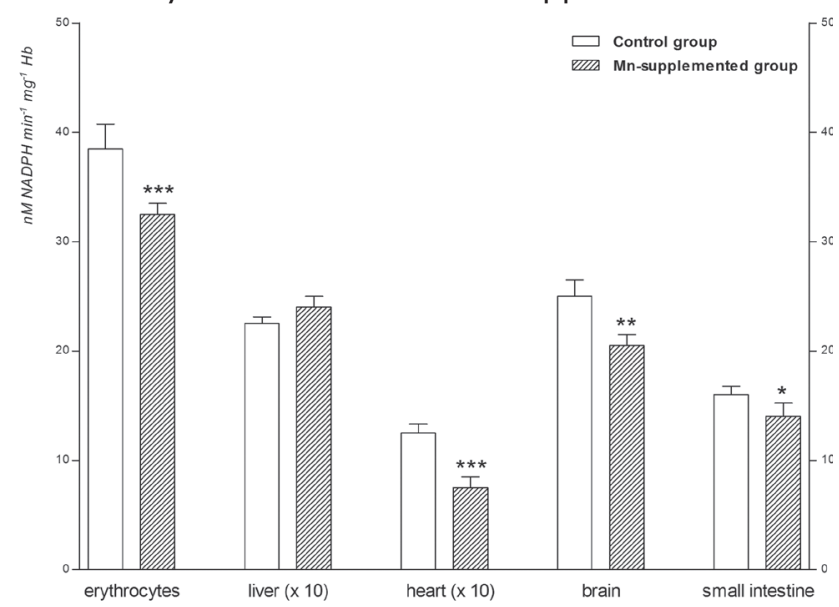

Figure 1. Specific GSH-Px activity in the erythrocytes, liver, heart, brain and small intestine of the control and rats supplemented with $\mathrm{Mn}$. (Means $\pm \mathrm{S}$.E. of the means of six animals in both groups; * $\mathrm{P}<0.05, * * \mathrm{P}<0.025, * * * \mathrm{P}<0.005)$.

all examined tissues, except in the liver.

CAT activity in rat tissues is presented in the Fiqure 2. The differences in the CAT activity

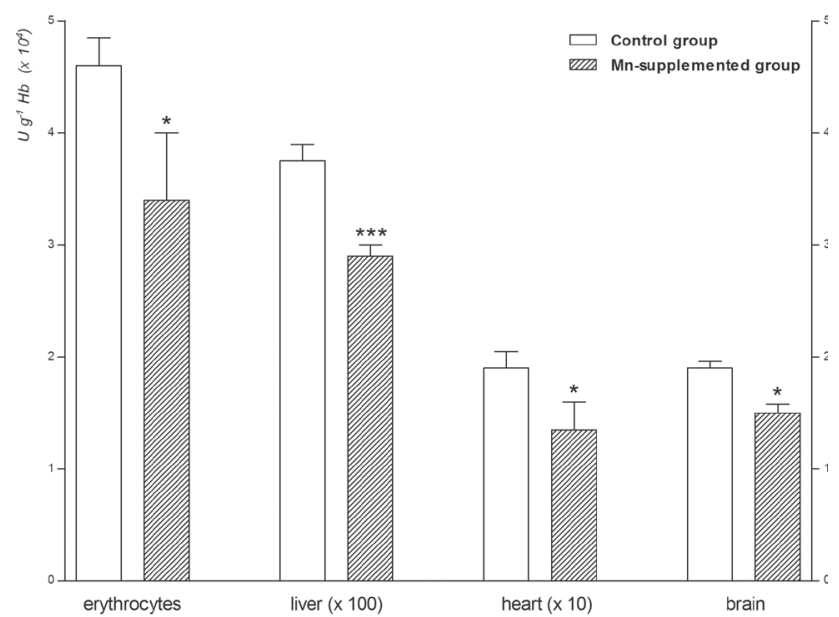

Figure 2. CAT activity in the rat tissues of the control and $\mathrm{Mn}$ supplemented group. (Means $\pm \mathrm{S}$.E. of the means of six animals in both groups; $* \mathrm{P}<0.05$, *** $\mathrm{P}<0.005)$. between the control and Mn-supplemented group were similar than for GSH-Px activity. In all examined tissues the decreases in CAT activity after $\mathrm{Mn}$-supplementation, were found.

The effect of Mn proteinate on GSH content in the plasma and tissues of control and Mn-treated rats is illustrated in the Figure 3 . The amount of GSH in all examined tissues of rat (except in small intestine) changed significantly in treated group in comparison to control, but the changes were not in the same direction. In the plasma $(P<0.005)$ and liver $(P<0.025)$, of $M n$-treated rats, the content of GSH was increased in comparison to the control, but in the heart and the brain $(P<0.005)$ the significant decrease in GSH content was found.

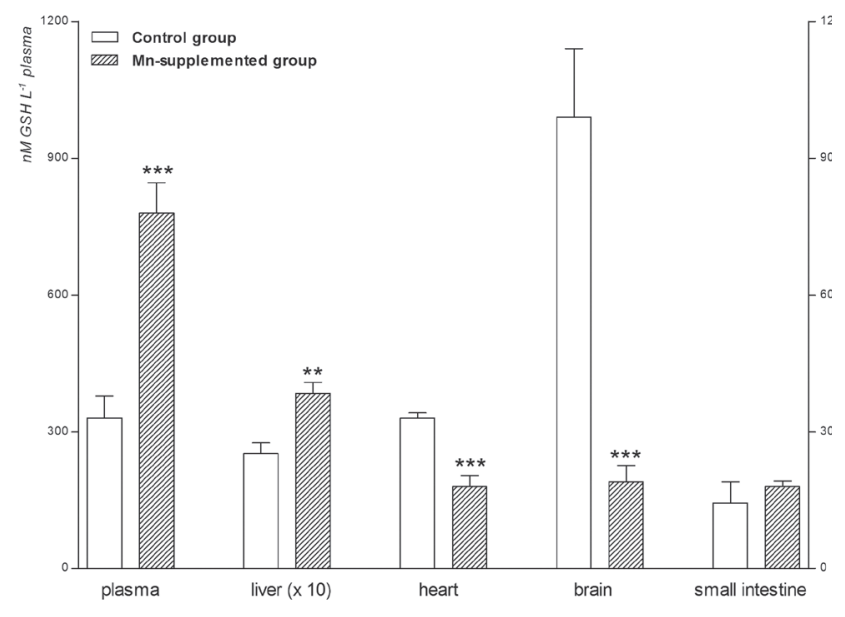

Figure 3. GSH contents in the plasma, liver, heart, brain and small intestine of the control and Mn-supplemented group. (Means \pm S.E. of the means of six animals in both groups; $* * P<0.025$, *** $\mathrm{P}<0.005)$.

\section{Discussion}

In this study, we have shown that supplementation of rats with $\mathrm{Mn}$ proteinates induces tissue-specific changes of antioxidant defense in vivo. Specifically, Mn supplementation increased the activities of CuZnSOD and GR in the heart, MnSOD and GR in the liver, and decreased activity of CuZnSOD in erythrocytes and GST in small intestine. On the other hand, the activities of CAT and GSH-Px decreased in all examined tissues in animals supplemented with $\mathrm{Mn}$. In addition, the content of GSH in the plasma and liver was higher after $\mathrm{Mn}$-supplementation, but lower in the heart and the brain. The effects of observed changes are discussed in more detail below.

In contrast to the number of enzymes activated by $\mathrm{Mn}$, there are few $\mathrm{Mn}$ metalloenzymes [27]. One of them is MnSOD, the antioxidant enzyme largely located in the mitochondrial matrix and encoded by nuclear gene. It is essential enzyme for all kind of oxygen-metabolizing cells, and act as an $\mathrm{O}_{2} \bullet-$ scavenger. MnSOD expression varies greatly, both among different types of cells and following changes in the environmental conditions. The increased level of MnSOD activity induced by $\mathrm{Mn}$ exposure has already been shown [28].

In the present study, the increase in MnSOD activity after $\mathrm{Mn}$ supplementation, was found only in the liver. These differences between examined 
rat tissues may be the results of variance in $\mathrm{Mn}$ concentration as a result of the treatment. After supplementation Paynter [27] found considerably greater changes in $\mathrm{Mn}$ concentration in liver in comparison to the heart, but the heart showed the greatest relative change in the activity of MnSOD in respond to changing the concentration of $\mathrm{Mn}$ in the diet. In this experiment the $\mathrm{Mn}$ were supplemented in the form of $\mathrm{MnCl}_{2}$. Our data indicate increased CuZnSOD activity only in the heart after supplementation with Mn proteinate, and no changes in the activity of MnSOD. This discrepancy may be the consequence of the different form of supplemented $\mathrm{Mn}\left(\mathrm{MnCl}_{2}\right.$ versus $\mathrm{Mn}$ proteinate) and differences in absorption and organ deposition. It is well known that $\mathrm{Mn}^{2+}$ could react with $\mathrm{O} 2 \bullet-$, and that the nature of the reaction depends on the ligand of the $\mathrm{Mn}$ ions. Thus, $\mathrm{Mn}$ may scavenging $\mathrm{O}_{2} \bullet-$ directly, or indirectly playing a role in metal-catalyzed dismutation reaction. $[29,30,31,32]$. The organic form of $\mathrm{Mn}$ used in this experiment is amino acid, peptide chelate and the way of absorption and the bioavailability is different in comparison to inorganic Mn salt. Because of that, it is possible that in our experiment more $\mathrm{Mn}$ is transported into the heart. The beneficial effect of $\mathrm{Mn}$ treatment in the heart was found in the work of Barandier et al. [33] where suppression of early oxidative burst by $\mathrm{Mn}$-supplementation after myocardial reperfusion injury, was observed. This protective effect of $\mathrm{Mn}$ against oxidative damage was explained by antioxidant properties of intracellularly accumulated $\mathrm{Mn}$ per se, independently of MnSOD. It is also known that $\mathrm{Mn}$ forms complexes with lactic, propionic, succinic, pyruvic and malic acids, which are efficient $\mathrm{O}_{2} \bullet-$ scavengers [27]. It has been shown that lactate accumulates during ischemia in the cardiomyocytes, accordingly, it was postulated that the observed antioxidant effect of $\mathrm{Mn}$ might be mediated, at least in part, by acid complex. Thus, it is shown that Mn complexes in heart have scavenger activity. It is of growing interest to use Mn complexes as pharmaceutical SOD agents (SOD mimics) to aid in reducing cellular damage by $\mathrm{O}_{2} \bullet-$ [34]. In the earlier work we shown [35] increase of CUZnSOD in heart and liver, and decreased in MnSOD activity in heart after supplementation with $\mathrm{Cu}$ and $\mathrm{Zn}$ chelate. Malecki et al. [36] found that, after parenteral administration, uptake of $\mathrm{Mn}$ was higher in the peripheral tissues than in the liver.

In the heart we also found decreased activity of CAT and GSH-Px, and the amount of GSH. As in the papers of Coassin et al. [37], and Stacey \& Klaassen [38] the peroxyl radical scavenging capacity of Mn (II) was shown. Decreased CAT and GSH-Px activities in the heart as well as in the blood of supplemented rat in our experiment may be explained by this $\mathrm{Mn}$ activity. After rat supplementation with $\mathrm{Mn}$, Scheuhammer \& Cherian [39] deduced that increased $\mathrm{Mn}$ levels in blood were almost totally accounted by increases in the erythrocyte fraction due to the treatment. At the same time, the concentration of $\mathrm{Mn}$ in the whole blood is five to 10 -folds greater than in serum [12]. In our experiment, in the plasma of supplemented group, but also in the liver, a significant increase in the amount of GSH was annotated. It is known that the level of GSH in plasma sustains the level of GSH in liver [28]. The GSH sulfhydryl/containing compound plays a crucial role in detoxification and cellular defense [40]. Higher level of GSH in the plasma of supplemented rats, may be result of tissue elimination of the accumulated GSH conjugates. Changes in GSH in the heart and the brain were in opposite direction. Many metal ions possess a high affinity for sulfhydryl groups and deplete GSH, due to metal binding to glutathione [41].

The same results, decreased amount of GSH, as well as the activity of CAT and GSH-Px what we find in the brain of Mn supplemented rats, Liccione and Maines [42] found in rat striatum exposed to Mn. Also, Hussain and Ali $[28,43]$ got the reduced GSH content in cerebellum as a consequence of administration of $\mathrm{MnCl}_{2}$. It is well known that $\mathrm{Mn}$ can induce neurological damage. $\mathrm{Mn}$ mostly accesses the brain via transferrin-dependent mechanism, but also as a free ion. This uptake may be mediated through an endogenous bloodbrain barrier $\mathrm{Mn}^{2+}$ transporter, or via channels or transporters that are specific for some other ions [44, 45]. Chronic exposure to Mn causes the degeneration of nigrostriatal dopaminergic neurons and Parkinson's syndrome. GSH depletion and upregulation of $\gamma$-glutamil transpeptidase, not accompanied by corresponding increase of GSH disulphide levels in the substantia nigra is also depicted after chronic Mn exposure. [42]. As it may be seen, even the low dose of Mn given in organic form, in our experiment made the changes in the activity and content of antioxidant components in the brain of rats.

The change in the activity of GST after Mnsupplementation was found only in small intestine. The acidic intestinal GST, according to Peters et al. [46] is most probably identical with GST Pi isolated from placenta, but in the hepatic preparation this isoform is hardly detectable. The difference between the effect of Mn supplementation on GST activity in small intestine and in the other examined tissues may be the consequence of different presence of GST isoforms in these tissues.

\section{Conclusions}

Treatment with $\mathrm{Mn}$ proteinate increased the activity of MnSOD only in the liver. Decreased activities of the most of examined antioxidant enzymes and the amount of GSH were noticed. Exception is the increased GSH amount in the plasma and liver and the increased activity of CuZnSOD in the heart. The observed changes in antioxidant defense after treatment with organic form of $\mathrm{Mn}$, may be explained by scavenging capacity of $\mathrm{Mn}$ for peroxyl and superoxide anion radical. According to all, we can assumed that the alterations in antioxidant defense in $\mathrm{Mn}$ supplemented group is a consequence of new prooxidant - antioxidant equilibrium.

\section{ACKNOWLEDGMENTS}

This work was supported by the Ministry of Education, Science and Technological Development of the Republic of Serbia, Grants No 173055 and 173054. 


\section{REFERENCES}

1. Law NA, Caudle MT, Pecoraro VL, Manganese redox enzymes and model systems: properties, structures, and reactivity. Adv Inorg Chem 1999;46:305- 440.

2. Recommended Dietary Alloeances. In National Research Council (NRC). (10th ed.) Washington, DC : National Academy Press 1989.

3. Toxicological Profile for Manganese. Agency for Toxic Substances and Disease Registry (ATSDR) Atlanta, GA, 1991.

4. Andrieu $S$, Is there a role for organic trace element supplements in transition cow health? Vet J 2008;176: 77-83.

5. Nemec LM, Rchards JD, Atwell CA, Diaz DE, Zantion GI, Gressley TF, Immune responses in lactating Holstein cows supplemented with $\mathrm{Cu}, \mathrm{Mn}$, and $\mathrm{Zn}$ as sulphates or methionine hydroxyl analogue chelates. J Dairy Sci. 2012;95:4568-4577.

6. Ashmead HD, Graff DJ, Ashmead HH, In: Intestinal absorption of metal ions and chelates. Ilinois, USA: C.C.Tomas. 1985.

7. Buzadzic B,Vucetic M, Jankovic A, Stancic A, Otasevic V, Korac B, Od Fentonove reakcije do savremenog koncepta redoks regulacije. Hrana i ishrana 2011;52:1-10.

8. Taylor A, Detection and monitoring of disorders of essential trace elements. Ann Clin Biochem 1996;33:486-510.

9. Frossared E, Bucher M, Machler F, Mozafar $A$, Hurrell R, Potential for increasing the content and bioavailability of $\mathrm{Fe}, \mathrm{Zn}$, and $\mathrm{Cu}$ in plants for human - nutrition. J Sci Food Agric 2000;80:861-879.

10. Swinkels JWGM, Kornegay ET, Zhou W, Lindemann MD, Webb KE Jr, Verstegen MWA, Effectiveness of zinc amino acid chelate and zinc sulfate in restoring serum and soft tissue zinc concentrations when fed to zinc-depleted pigs. J Anim Sci 1996;74:2420-2430.

11. Apines MJS, Satoh S, Kiron V, Watanabe T, Aoki T, Availability of supplemental amino acidchelated trace elements in diets containing tricalcium phosphate and phytate to rainbow trout, Oncorhynchus mykiss. Aquaculture 2003;225:431-444.

12. Patton RS, Chelated minerals: what are they, do they work? Feedstuff 1990; 62: 14.

13. Spears JW, Kegley EB, Ward JD, Bioavailability of organic, inorganic trace minerals explored, Feedstuffs 1991;27:12.

14. Du Y, Hemken RW, Harmon RJ, Clarc TW, Harmon DL, Trammell DS, Bioavailabilities of $\mathrm{Cu}$ for lactating Holsteins in copper proteinate and cupric sulfate as influenced by iron. J Dairy Sci 1995;78:323-328.

15. Ali SF, Duhart HM, Newport GD, Lipe GW, Slikker WJr, Manganese induced reactive oxygen species: comparison between $\mathrm{Mn2+}$ and Mn3+. Neurodegeneration 1995;2:329334.

16. Daly MJ, Gaidamakova EK, Matrosova VY, Vasilenko A, Zhai M, Venkateswaran A, Hess $M$, Omelchenko MV, Kostandarithes HM, Markova KS, Wackett LP, Fedrickson JK, Ghosal
D, Accumulation of $\mathrm{Mn}$ (II) in Deinococcus radiodurans fascilitates gamma-radiation resistance. Science 2004;306:1025-1028.

17. Sanchez RJ, Srinivasan C, Munroe WH, Wallace MA, Martins J, Kao TY, Le K, Gralla EB, Valentine JS, Exogenous manganous ion at milimolar levels rescues all known dioxigen-sensitive phenotypes of yeast lacking CuZnSOD. J Biol Inorg Chem 2005;10:913-923.

18. Florers SC, Merecki JC, Harper KP, Bose SK, Nelson SK, McCord J, Tat protein of human immunodeficiency virus type 1 represses expresion of manganese superoxide dismutase in HeLa cells. Proc Natl Acad Sci USA 1993;90:7632-7636.

19. Takada Y, Noguchi T, Okabe T, Kayaiyama M, Superoxide dismutase in various tissues from rabbits bearing the $\mathrm{Vx}-2$ carcinoma in maxillary sinus. Cancer Res1982;42:4233-4235.

20. Misra HP, Fridovich I, The role of superoxide anion in the autooxidation of epinephrine and a simple assay for superoxide dismutase. J Biol Chem 1972;247:3170-3175.

21. Paglia $D E$, Valentine $W N$, Studies on the quantitative and qualitative characterization of erythrocyte glutathione peroxidases. J Lab Clin Med 1967;70:74-77.

22. Glatzle D, Vuilleumier JP, Weber F, Decker K, Glutathione reductase tests with whole blood a convenient procedure for the assessment of the riboflavin status in humans. Experientia 1974;30:665-668

23. Habig WH, Pabst MJ, Jakoby WB, Glutathione-Stransferases. J Biol Chem 1974; 249: 7130-7139.

24. Griffith OW, Determination of glutathione and glutathione disulfide using glutathione reductase and 2-vinyl pyridine. Anal Biochem 1980;106:207-212.

25. Lowry $\mathrm{OH}$, Rosenbrough $\mathrm{NJ}$, Farr $\mathrm{AL}$, Randall RJ, Protein measurement with the Folin phenol reagent. J Biol Chem 1951;193:265-275.

26. Hoel PG, Introduction to mathematical statistics. New York: John Wiley and Sons. 1966.

27. Paynter DI, Changes in activity of the manganese superoxide dismutase enzyme in tissue of the rat with changes in dietary manganese. J Nutr 1980;110:437- 447.

28. Hussain S, Ali SF, Antioxidant enzymes: Developmental profiles and their role in metal induced oxidative stress. In: Handbook of developmental neurotoxicology, New York: Academic Press. 353-369, 1998.

29. Halliwell B, Manganese ions, oxidation reactions and the superoxide radical. Neurotoxicology 1984;5:113-118.

30. Kons $Y$, Takahashi M, Asada K, Oxidation of manganous pyrophosphate by superoxide radicals and illuminatiated spinach chloroplasts. Arch Biochem Biophys 1976;174:454-462.

31. Archibald FS, Fridovich I, The schavening of superoxide radical by manganous complexes in vitro. Arch Biochem Biophys 1982;214:452463.

32. Reddi AR, Jensen LT, Naranuntarat A, Rosenfeld $L$, Leung RS, Culotta VC, The overlapping roles of manganese and $\mathrm{Cu} / \mathrm{Zn}$ SOD in oxidative stress protection. Free Radic 
Biol Med 2009;46:154-162.

33. Barandier CE, Boucher FR, de Leiris JP, Manganese reduces myocardial reperfusion injury on isolated rat heart. J Mol Cell Cardiol 1998;30:834-847

34. Iranzo $\mathrm{O}$, Manganese complexes displaying superoxide dismutase activity: A balance between different factors. Bioorganic Chem 2011;39:73-87.

35. Buzadžić B, Korać B, Lazić T, Obradović D, Effect of supplementation with $\mathrm{Cu}$ and $\mathrm{Zn}$ on antioxidant enzyme activity in the rat. Food Res Int 2002;35:217-20.

36. Malecki EA, Lo HC, Yang $H$, Davis CD, Ney DM, Greger $\mathrm{JL}$, Tissue manganese concentrations and antioxidant enzyme activities in rats given total paranteral nutrition with and without supplemental manganese. J Paranter Enteral Nutr 1995;4:222-226.

37. Coassin M, Ursini F, Bindoli A, Antioxidant effect of manganese. Arch Biochem Biophys 1992;299:330-333.

38. Stacey $\mathrm{NH}$, Klaassen $\mathrm{CD}$, Inhibition of lipid peroxidation without prevention of cellular injury in isolated rat hepatocytes. Toxicol Appl Pharmacol 1981;30,8-18.

39. Scheuhammer AM, Cherian MG, The influence of manganese on the distribution of essential trace elements. II. The tissue distribution of manganese, magnesium, zinc, iron and copper in rats after chronic manganese exposure. J Toxicol Environ Health 1983;12:361-370.

40. Meister A, Anderson ME, Glutathione. Ann Rev Biochem 1983;52:711-760.

41. Sergent O, Morel I, Cillard J, Involvement of metal ions in lipid peroxidation: biological implications. Met Ions Biol Syst 1999;36:251287.

42. Liccione JJ, Maines MD, Selective vulnerability of glutathione metabolism and cellular defense mechanisms in rat striatum to manganese. J Pharmacol Exp Ther 1988;247:156-161.

43. Hussain S, Lipe GW, Slikker WJr, Ali SF, The effects of chronic exposure of manganese on antioxidant enzymes in different regions of the brain. Neurosci Res Commun 1997;21:135143.

44. Quentin RS, Rabin O, Chikhale GE, Delivery of metals to brain and the role of the bloodbrain barrier. In: Connor, Metals and oxidative damage in neurological disorders, New York: Plenum press. 1997; 113-130.

45. Rabin O, Hegedus L, Bourre JM, Smith $\mathrm{QR}$, Rapid brain uptake of manganese (II) across the blood-brain barrier. J Neurochem 1991;61:509-517.

46. Peters $W H$, Roelofs HM, Nagengast FM, Van Tongeren $\mathrm{JH}$, Human intestinal glutathione S-transferases. Biochem J 1989;2:471-476.

\section{Antioksidativna odbrana u tkivima pacova nakon suplementacije organskom formom mangana}

Bato Korać1,2, Milica Vučetic ${ }^{1}$, Aleksandra Janković ${ }^{1}$ Ana Stančić ${ }^{1}$, Vesna Otašević ${ }^{1}$ Biljana Buzadžići

Kratak sadržaj: $U$ radu je ispitivan efekat suplementacije helatom mangana na aktivnost antioksidativnih enzima: bakar cink- i mangansuperoksid dismutaze (CuZnSOD i MnSOD), katalaze (engl. catalase, $C A T)$, glutation peroksidaze (engl. glutathione peroxidase, GSH-PX), glutation reduktaze (GR) i na količinu glutationa (GSH) u krvi, jetri, mozgu, srcu i tankom crevu pacova. Povećan unos Mn od 34\% iznad

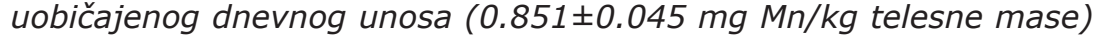
indukovao je promene u antioksidativnoj odbrani u tkivima pacova. Smanjenje aktivnosti enzima koji konvertuju perokside: CAT i GSHPx zabeleženo je u svim ispitivanim tkivima (osim u aktivnosti GSHPx u jetri). Količina GSH je bila povećana u plazmi i jetri, a smanjena u srcu i mozgu suplementisanih životinja. Tretman Mn povećao je aktivnost MnSOD samo u jetri, a CuZnSOD aktivnost u srcu. Ove promene $u$ antioksidativnoj odbrani snažno su povezane sa novouspostavljenim redoks profilom $u$ ispitivanim tkivima posle suplementacije sa $\mathrm{Mn}$.

Ključne reči: Mangan; metalni helati; antioksidantni enzimi; glutation. 